\title{
Freeze-drying of ampicillin solid lipid nanoparticles using mannitol as cryoprotectant
}

\author{
Faezeh Alihosseini ${ }^{1}$, Solmaz Ghaffari ${ }^{1,2, *}$, Ali Reza Dabirsiaghi ${ }^{3}$, Setareh Haghighat $^{4}$
}

${ }^{1}$ Department of Medical Nanotechnology, Faculty of Advanced Sciences and Technology, Pharmaceutical Sciences Branch, Islamic Azad University, IAUPS, Tehran, Iran, ${ }^{2}$ Young Researchers and Elite Club, Pharmaceutical Sciences Branch, Islamic Azad University, IAUPS, Tehran, Iran, ${ }^{3}$ Department of Pharmaceutics, Faculty of Pharmacy, Pharmaceutical Sciences Branch, Islamic Azad University, IAUPS, Tehran, Iran, ${ }^{4}$ Department of Microbiology, Faculty of Advanced Sciences and Technology, Pharmaceutical Sciences Branch, Islamic Azad University, IAUPS, Tehran, Iran

\begin{abstract}
Solid lipid nanoparticles (SLNs) are interesting colloidal drug-delivery systems, since they have all the advantages of the lipid and polymeric nanoparticles. Freeze-drying is a widely used process for improving the stability of SLNs. Cryoprotectants have been used to decrease SLN aggregations during freeze-drying. In this study Ampicillin was chosen to be loaded in a cholesterol carrier with nano size range. To support the stability of SLNs, freeze-drying was done using mannitol. Particle size, drug release profile and antibacterial effects were studied after freeze-drying in comparison with primary SLNs. Preparations with 5\% mannitol showed the least particle size enlargement. The average particle size was 150 and $187 \mathrm{~nm}$ before and after freeze-drying, respectively. Freeze-drying did not affect the release profile of drug loaded nanopartilces. Also our study showed that lyophilization did not change the antimicrobial effect of ampicillin SLNs. DSC analysis showed probability of chemical interaction between ampicillin and cholesterol.
\end{abstract}

Uniterms: Solid lipid nanoparticles. Stability. Cryoprotectant. Freeze-drying. Antibacterial efficacy. Particle size

Nanoparticulas lipídicas sólidas (NLSs) são sistemas coloidais de liberação interessantes, uma vez que reúnem todas as vantagens de nanopartículas lipídicas e poliméricas. A liofilização é um processo amplamente utilizado para melhorar a estabilidade das NLSs e os crioprotetores têm sido usados para diminuir a agregação destas durante esse processo. Neste estudo, a ampicilina foi escolhida para ser encapsulada em um carreador de colesterol de escala nanométrica. Para manter a estabilidade das NLSs, a liofilização foi realizada utilizando-se manitol. O tamanho de partícula, o perfil de liberação do fármaco e os efeitos antibacterianos foram estudados após a liofilização em comparação com a NLSs primária. De acordo com os resultados, as preparações que contêm 5\% de manitol mostraram o menor aumento do tamanho de partícula. Os resultados de tamanhos médio foram de 150 e $187 \mathrm{~nm}$ antes e depois da liofilização, respectivamente. O perfil de liberação prolongada, bem como o efeito antimicrobiano da ampicilina NLSs não foram alterados após a liofilização. A análise por DSC evidenciou provável interação entre a ampicilina e o colesterol.

Unitermos: Nanopartícula lipídica sólida. Estabilidade. Crioprotetor. Liofilização. Eficiênca antibacteriana. Tamanho de particular

\footnotetext{
*Correspondence: Solmaz Ghaffari. Department of Medical Nanotechnology. Faculty of Advanced Sciences and Technology. Pharmaceutical Sciences Branch. Islamic Azad University - IAUPS. Tehran, Iran. E-mail: ghaffari.s@iaups.ac.ir and soligh@yahoo.com
} 


\section{INTRODUCTION}

Solid lipid nanoparticles (SLNs) as colloidal carrier systems have the advantages of traditional systems but avoid some of their major disadvantages (Mehnert, Mader, 2001; Hu et al, 2004). Some advantages of SLNs are possibility of the incorporation of lipophilic and hydrophilic drugs, possibility of controlling drug release and drug targeting, increased drug stability, high drug payload, lack of biotoxicity of the carrier, no problems with respect to large-scale production, sterilization possibility, and good tolerability (Zhang et al., 2006; Varshosazs et al., 2010; Mukherjee et al, 2009). The enhancement of antibacterial efficacy of antibiotics using SLNs as a carrier was reported as one of the advantages of these colloidal systems (Varshosaz et al., 2010; Alihoseyni et al., 2014). Freeze-drying has been considered as a good technique to improve the long-term stability of colloidal nanoparticles. Other studies show that poor stability in an aqueous medium is a major barrier against the clinical use of nanoparticles (Abdelwahed et al., 2006). Also freeze-drying may generate many stresses that could destabilize colloidal suspension of nanoparticles before turning them to dried particles (Abdelwahed et al., 2006). Cryoprotectants have been used to decrease SLN aggregations due to the stress during the process of freeze-drying (Subedi, Kang, Choi, 2009). Glucose, sucrose, trehalose, lactose, mannitol, sorbitol, aerosol, maltose, polyvinyl pyrrolidone, fructose, dextran, glycerol, polyvinyl alcohol, glycine, hydroxypropyl- $\beta$-cyclodextrin and gelatin were used as cryoprotectant in several studies (Mehnert, Mader, 2001; Ghaffari et al., 2011). In this study we studied the effect of mannitol in different percentages as cryoprtecant in freeze-drying process on particle size, morphology, drug release profile and antibacterial efficacy of ampicillin SLNs. Our goal was to prepare freeze-dried ampicillin SLNs and optimize lyophilization process to have minimum impact on their physicochemical and antimicrobial properties.

\section{MATERIAL AND METHODS}

\section{Material}

Cholesterol (Merck, Germany) was used as lipid material of SLNs. Tween 80 (Merck) was used as surfactant. Ampicillin (Kosar Pharmaceutical Co., Tehran, Iran) was used as the active pharmaceutical ingredient. Ethanol and acetone (Merck Chemical Company, Germany) were organic solvents.

\section{Preparation of ampicillin SLNs}

At first $350 \mathrm{mg}$ of cholesterol was added to the mixture of acetone and ethanol in ratio of 1 to 3 , then the mixture was heated in a water bath at $75^{\circ} \mathrm{C}$. Ampicillin was added to deionized water containing $1 \%(\mathrm{w} / \mathrm{w})$ tween 80 as surfactant (Varshosaz et al., 2010; Alihoseyni et al., 2014). After that, the hot oily phase was added to water at room temperature under homogenizing at $11,000 \mathrm{rpm}$, using IKA ${ }^{\circledR}$ (Staufen, Germany) T-18 basic, Ultra-Turrax ${ }^{\circledR}$ (Germany) for 20 minutes. The prepared mixture was sonicated at $45-50^{\circ} \mathrm{C}$ for 7 minutes, using a bath-sonicator system (Tecna 6; Tecno-Gaz, Sala Baganza, Italy). SLNs were made when the mixture temperature was decreased to room temperature. The particle size of the nanoparticles was measured by a Zetasizer (ZEN3600; Malvern Instruments, Britain).

\section{Determination of ampicillin}

The spectrophotometric scan of ampicillin was done on 200-400 nm wavelength, the maximum absorption was seen on $208 \mathrm{~nm}$, the linearity of the results was studied for solutions with different concentration (25-200 ppm) in buffer and water and $\mathrm{R}^{2}$ of the method were respectively 0.993 and 0.995 .

\section{Drug loading efficiency}

For determination of drug loading efficiency, the samples were centrifuged at 26,000 rpm for 45 minutes, at $4{ }^{\circ} \mathrm{C}$ by using a Sigma Laboratories centrifuge (Osterode am Harz, Germany). The drug concentration in the supernatant was analyzed using spectrophotometer (Shimadzu, Japan) at $208 \mathrm{~nm}$ and the drug-loading efficiency was calculated by using the following equation. (Kimberly, Tabrizian 2005; Ghaffari et al. 2012; Alihoseyni et al. 2014) The results reported as mean of three analyses with standard deviation.

Drug Loading efficacy $(L E \%)=\frac{\text { Drug }_{\text {total }}-\text { Drug }_{\text {sup ernatant }}}{\text { Drug }_{\text {total }}} \times 100 \mathrm{tr}$

\section{Freeze-drying}

The particles were freeze-dried using freeze-dryer (Lyotrap/Plus, UK) at $-80{ }^{\circ} \mathrm{C}$ under 0.4 bar. Different amounts of mannitol $(5,10$ and $15 \%)$ was used as cryoprotectant.

\section{Morphology study}

Morphology of the nanoparticles was characterized 
by scanning electron microscopy (SEM) before and after freeze-drying. The nanoparticles were mounted on aluminum stubs, sputter-coated with a thin layer of $\mathrm{Au} / \mathrm{Pd}$, and examined by using an SEM (Philips XL30, Almelo, Netherlands) instrument.

\section{Release studies}

Release study was done using the dialysis sack method by DO405 Dialysis tubing 23x15 mm (Sigma, Germany). Five $\mathrm{mL}$ of the formulation before and after freeze-drying was placed in dialysis membrane (10-12 $\mathrm{KD}$ ) immersed in $50 \mathrm{~mL}$ phosphate buffer solution ( $\mathrm{pH} 7.4$ ) at room temperature $\left(25 \pm 2{ }^{\circ} \mathrm{C}\right)$. The freeze dried particles were diluted in $5 \mathrm{~mL}$ of deionized water before placing in dialysis membrane. The free drug which was not loaded on SLNs was removed using centrifuge at 26,000 rpm for 45 minutes, at $4{ }^{\circ} \mathrm{C}$ by a Sigma Laboratories centrifuge. One $\mathrm{mL}$ samples were withdrawn in predetermined time intervals and drug concentration was analyzed using UV spectrophotometry (Shimadzu, Japan) method at $208 \mathrm{~nm}$. (Varshosaz et al., 2010, Alihoseyni et al, 2014).

\section{DSC analysis}

DSC thermograms were obtained using: DSC 823e Mettler, Swiss. A certain amount of dried nanoparticle powder was crimped in a standard aluminum pan and heated from $25-400{ }^{\circ} \mathrm{C}$ at a heating rate of $10^{\circ} \mathrm{C} / \mathrm{min}$ under constant purging of nitrogen.

\section{Antimicrobial activity of SLNs}

The antimicrobial activity of nanoparticles before and after freeze-drying was studied using well diffusion test. P. aeruginosa (ATCC 27853) and E. coli (ATCC 25922) were used as gram negative pathogenic strains. The bacterial suspensions with a cell density equivalent to $0.5 \mathrm{McF}$ arland $\left(1.5 \times 10^{8} \mathrm{CFU} / \mathrm{mL}\right)$ were transferred individually onto the surface of Muller-Hinton agar plates using sterile swabs. Wells with $8 \mathrm{~mm}$ diameters were prepared by punching and removing the agar to form a well. Aliquots of $100 \mu \mathrm{L}$ of each original SLNs after preparation and SLNs after freeze-drying, were delivered into the wells as the test samples. After incubation time for 48 hours, at $35^{\circ} \mathrm{C}-37^{\circ} \mathrm{C}$, the zones of inhibition around the wells were measured in $\mathrm{mm}$ using a caliper.

\section{RESULTS AND DISCUSSION}

\section{Particle size}

The evaluation of particles using Malvern zeta sizer (ZEN3600) showed a normal distribution of particle size before and after freeze-drying when the percentage of cryoprotectant was equal to $5 \%$. Results showed that more than $70 \%$ of particles were smaller than $95 \mathrm{~nm}$ in size also $85 \%$ and $96 \%$ of prepared particles were smaller than 150 and $285 \mathrm{~nm}$ before freeze-drying. More than $77 \%$ of particles were smaller than $69.7 \mathrm{~nm}$, more than $92 \%$ of particles were smaller than $95.3 \mathrm{~nm}$, more than $98 \%$ and $99 \%$ were smaller than 130 and $208 \mathrm{~nm}$, after lyophilization. Figure 1 shows the particle size distribution profile after freeze-drying. This result confirmed that lyophilization of ampicillin SLNs did not show any effect on particle size of prepared particles. Comparison of particle size of SLNs after lyophilization, shows that 5\% mannitol as cryoprotectant yileds the smallest particles.

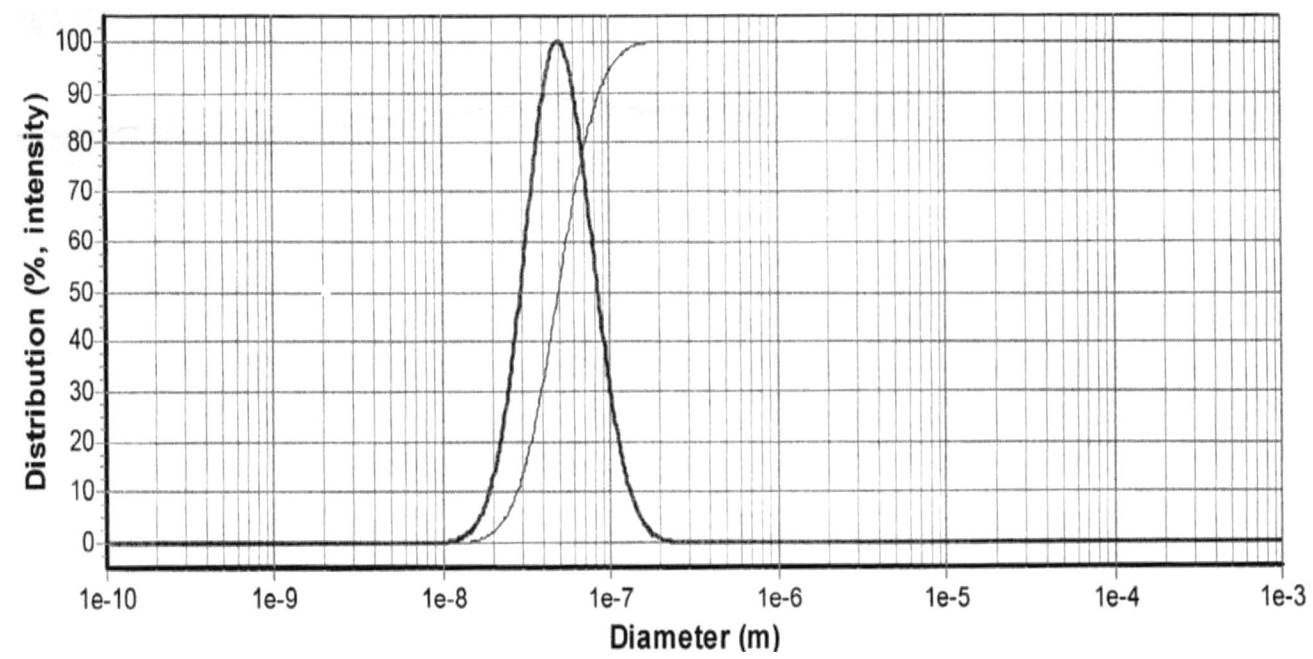

FIGURE 1 - Particle size distribution of ampicillin solid lipid nanoparticles after freeze-drying using 5\% mannitol as cryoprotectant. 
The average particle size was 187,911 and $1930 \mathrm{~nm}$ for formulations with 5, 10 and 15\% mannitol. So the lyophilized particles with 5\% mannitol were chosen to continue the studies. Varshosaz et al. showed that sucrose as cryoprotectant in concentration of $12 \%$ would be suitable choice to avoid particle size increase during freeze-drying process of SLNs.

\section{SEM study}

Figures $2 \mathrm{a}$ and $2 \mathrm{~b}$ show the morphologies of the freeze-dried formulations in comparison with nonlyophilized particles respectively. Results showed that no significant enlargement of particle size was happened after freeze-drying.
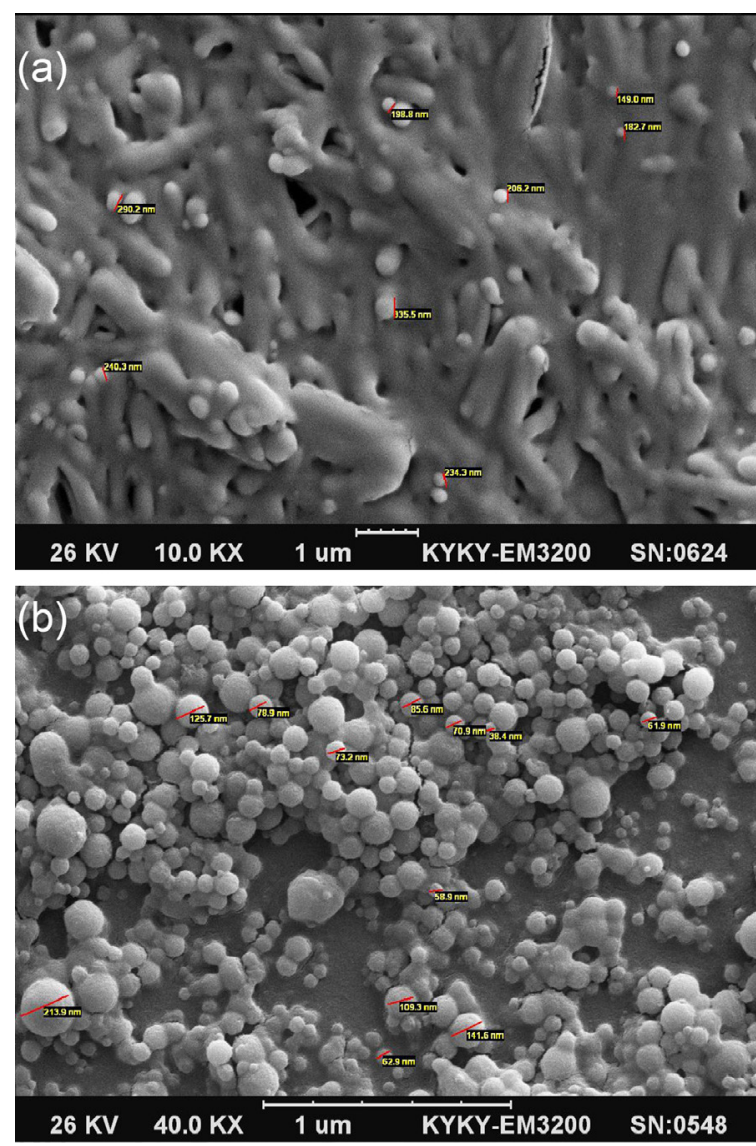

FIGURE 2 - Scanning electron microscopy pictures of ampicillin solid lipid nanoparticles after freeze-drying (a), before freezedrying in primary preparation (b).

\section{Drug loading efficacy}

Our results showed $77 \pm 4 \%$ drug loading efficacy. The percentage of drug loading was used for calculations of drug release profile as well.

\section{Drug release studies}

Figure 3 compares the release profile of ampicillin from SLNs before and after lyophilization which lasts for about $24 \mathrm{~h}$ and releases about $98 \%$ of ampicillin during this period by a sustained behavior. No significant difference was observed between two profiles. No burst effect was established for lyophilized SLNs. Varshosaz et al. (2012), reported burst effect after freeze-drying of amikacin SLNs.

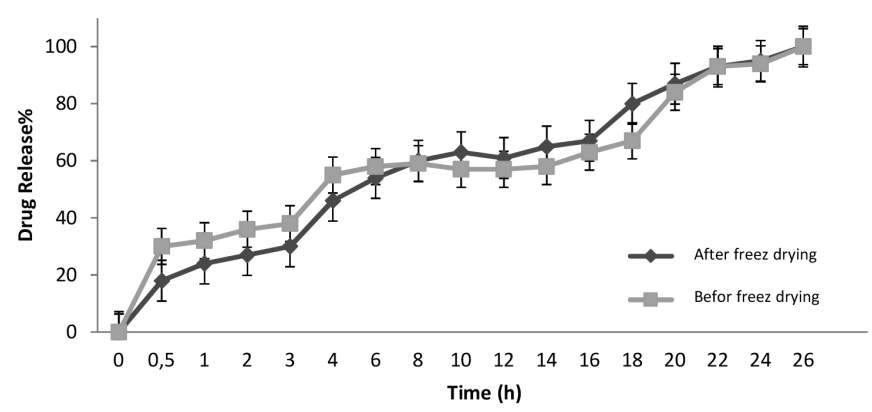

FIGURE 3 - Release profile of ampicillin solid lipid nanoparticles before and after freeze-drying.

\section{Antimicrobial activities}

The antimicrobial activity of lyophilized SLNs of ampicillin after redispersion in water is shown in Figure 4a and $4 \mathrm{~b}$ against $P$. aeruginosa and E. coli. Results showed that ampicillin loaded nanoparticles increase antibacterial efficacy of ampicillin in comparison with free drug. Therefore, lyophilization process did not have impact on antimicrobial activity of SLNs as carrier of ampicillin. Enhanced antibacterial properties of drug loaded SLNs was reported by Ghaffari et al. (2011) before.

\section{DSC analysis}

Differential Scanning Calorimetry thermograms (DSC) for pure cholesterol, ampicillin and ampicillinloaded SLNs were shown in Figure 5. The endotherm of melting point of cholesterol has shifted from $132{ }^{\circ} \mathrm{C}$ to about $166^{\circ} \mathrm{C}$ in the SLNs of ampicillin. The melting temperature of ampicillin is also seen in $112^{\circ} \mathrm{C}$ and $137^{\circ} \mathrm{C}$ in the thermogram of pure ampicillin. However, the melting point of the drug has been covered in the SLNs and only the endotherm of probable shifted melting point of cholesterol is observable. Sustained release of ampicillin from SLNs can be related to probable hydrogen bond formation between cholesterol and ampicillin which can be seen in DSC thermograms. 

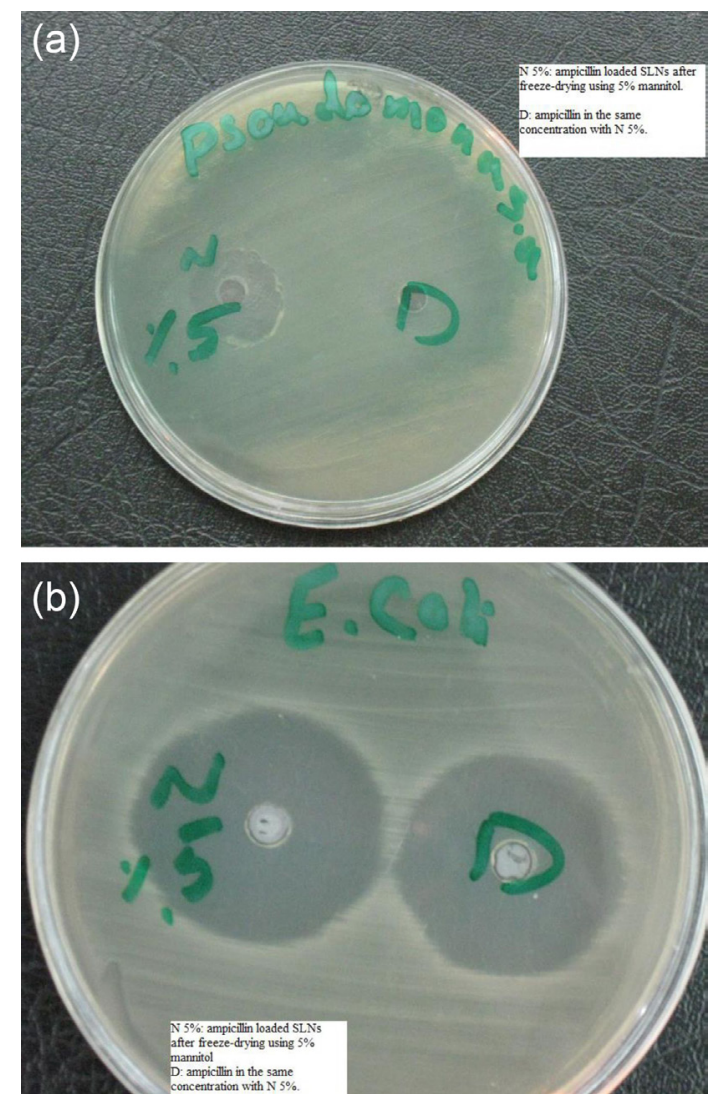

FIGURE 4 - Photographs of the zone of inhibition produced by free ampicillin and its SLNs in freeze-dried SLNs against $P$. aeruginosa(a) and E. coli (b).

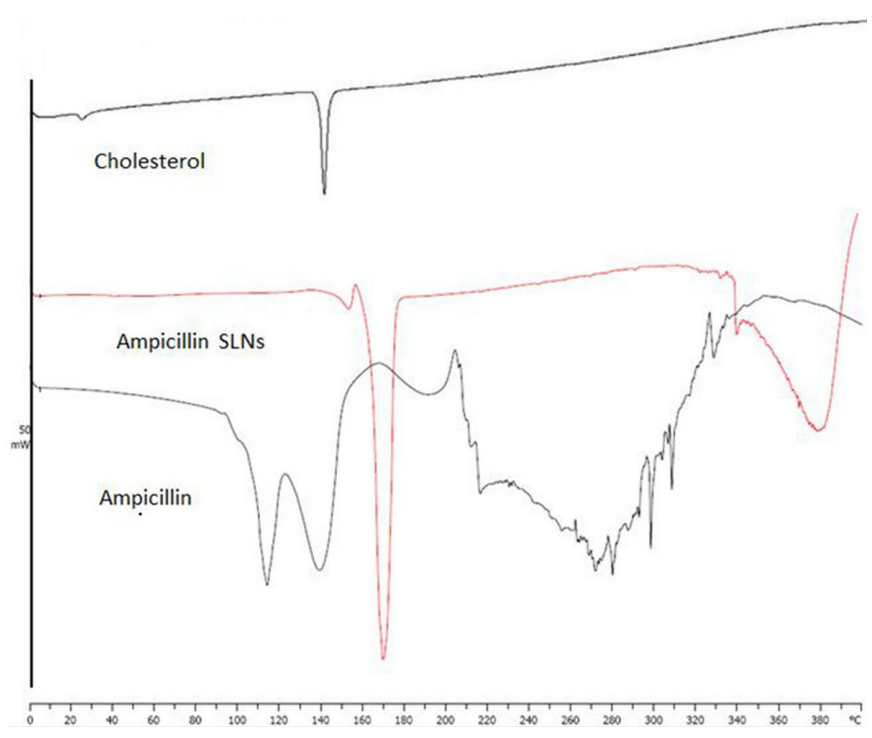

FIGURE 5 - DSC thermograms of raw materials and freeze-dried SLNs of ampicillin.

\section{CONCLUSION}

Our goal was to prepare freeze-dried ampicillin SLNs and optimize lyophilization process using proper croprotectant to have minimum impact on their physicochemical and antimicrobial properties. Mannitol $5 \%$ provided the optimum condition to avoid particle aggregation. Release profile, DSC analysis, SEM of lyophilized SLNs and antibacterial efficacy were studied and the results showed no burst effect on release profile of ampicillin without significant increase in drug release rate. DSC analysis showed probable interaction between ampicillin and cholesterol. The SEM photographs showed spherical shape of the freeze-dried particles. As the final conclusion, freezing of SLNs of ampicillin dispersion at $-80^{\circ} \mathrm{C}$ and the addition of $5 \%$ mannitol before lyophilization inhibited the aggregation of the nanoparticles after reconstitution.

\section{ACKNOWLEDGEMENTS}

The authors would like to acknowledge the research vice chancellor of Islamic Azad University, Pharmaceutical sciences branch for technical support, Prof. S. Mahdi Rezayat Sorkhabadi for scientific support, Mr. Rezae for SEM pictures, Hedieh Ghaffari and Dr. Shirzad Azarmi for English edit of manuscript and Mrs. Loebenberg for Portuguese translation of abstract.

\section{REFERENCES}

ABDELWAHED, W.; DEGOBERT, G.; STAINMESSE, S.; FESSI, H. Freeze-drying of nanoparticles: Formulation, process and storage considerations. Adv. Drug. Del. Rev., v.58, n.15, p.1688-1713, 2006.

ALIHOSEYNI, F.; GHAFFARI, S.; DABIRSIAGHI, A.R.; HAGHIGHAT, S. Preparation and evaluation of ampicillin solid lipid nanoparticles. World J. Pharm. Sci., v.9, n.2, p.914-920, 2014.

CHACON, M.; MOLPECERES, J.; BERGES, L.; GUZMAN, M.; ABERTURAS, M.R. Stability and freeze-drying of cyclosporine loaded poly(D,L lactide-glycolide) carriers. Eur. J. Pharm. Sci., v.8, p.99-107, 1999.

GHAFFARI, S.; VARSHOSAZ, J.; HARIRIAN, I.; KHOSHAYAND, MR.; AZARMI, SH.; GAZORI, T. Ciprofloxacin loaded alginate/chitosan and solid lipid nanoparticles, preparation, and characterization. J. Dis. Sci. Technol., v.33, n.5, p.685-689, 2012.

GHAFFARI, S.; VARSHOSAZ, J.; SAADAT, A.; ATYABI, F. Stability and antimicrobial effect of amikacin-loaded solid lipid nanoparticles. Int. J. Nanomed., v.6, p.35-43, 2011. 
HU, F.Q.; HONG, Y.; YANG, H. Preparation and characterization of solid lipid nanoparticles containing peptide. Int. J. Pharm., v.273, n.1-2, p.29-35, 2004.

KONAN, Y.N.; GURNY, R.; ALLEMANN, E. Preparation and characterization of sterile and freeze-dried sub-200 nm nanoparticles. Int. J. Pharm., v.233, p.239-252, 2002.

KIMBERLY, LD.; TABRIZIAN, M. Effect of experimental parameters on the formation of alginate-chitosan nanoparticles and evaluation of their potential application as DNA carrier. J. Biomater. Sci. Polymer Ed., v.16, n.1, p.43-56. 2005.

LEE, M.K.; KIM, M.Y.; KIM, S.; LEE, J. Cryoprotectants for freeze-drying of drug nano suspensions: effect of freezing rate. J. Pharm. Sci., v.98, n.12, p.4808-4817, 2009.

MEHNERT, W.; MADER, K. Solid lipid nanoparticles: production, characterization, and applications. Adv. Drug. Deliv. Rev., v.47, n.2-3, p.165-196, 2001.

MUKHERJEE, S.; RAY, S.; THAKUR, R.S. Solid lipid nanoparticles: a modern formulation approach in drug delivery system. Ind. J. Pharm. Sci., v.71, n.4, p.349-358, 2009.

OHSHIMA. H.; MIYAGISHIMA, A.; KURITA, T.; MAKINO, Y.; LWAO, Y.; SONOBE, T.; ITAI. S. Freeze-dried nifedipine lipid nanoparticles with longterm nano dispersion stability after reconstitution. Int. J. Pharm., v.377, p.180$184,2009$.
RODRIGUEZ,A.; SOLINIS, M.A.; GASCON, A.R.; PEDRAZ, J.L. Short and longterm stability study of lyophilized solid lipid nanoparticles for gene therapy. Eur. J. Pharm. Biopharm., v.71, p.181-189, 2009.

SUBEDI, R.K.; KANG, K.W.; CHOI, H.K. Preparation and characterization of solid lipid nanoparticle loaded with doxorubicin. Eur. J. Pharm. Sci., v.37, n.3-4, p.508-513, 2009.

VARSHOSAZ, J.; GHAFFARI, S.; KHOSHAYAND, M.R.; ATYABI, F.; JAFARIAN DEHKORDI, A.; KOBARFARD, F. Optimization of freeze-drying condition of amikacin solid lipid nanoparticles using D-optimal experimental design. Pharm. Dev. Technol., v.17, n.2, p.187-194, 2012.

VARSHOSAZ, J.; GHAFFARI, S.; KHOSHAYAND, M.R.; ATYABI, F.; AZARMI, S.; KOBARFARD, F. Development and optimization of solid lipid nanoparticles of amikacin by central composite design. J. Liposome Res., v.20, n.2, p.97-104, 2010.

YANG, S.; ZHU, J. Preparation and characterization of camptothecin solid lipid nanoparticles. Drug. Dev. Ind. Pharm., v.28, n.3, p.265-274, 2002.

ZHANG, N.; PING, Q.; HUANG, G.; XU, W. Lectin-modified solid lipid nanoparticles as carriers for oral administration of insulin. Int. J. Pharm., v.327, n.1-2, p.153-159, 2006.

ZIMMERMANN, E.; MULLER, R.H.; MADER, K. Influence of different parameters on reconstitution of lyophilized SLN. Int. J. Pharm., v.196, n.2, p.211-213, 2000.

Received for publication on $29^{\text {th }}$ January 2015 Accepted for publication on $16^{\text {th }}$ August 2015 